\title{
Correction to: Seismic soil-structure interaction analysis of structure with shallow foundation using response spectrum method
}

\author{
Zhidong Gao $^{1} \cdot \mathrm{Mi} \mathrm{Zhao}^{1} \cdot$ Xiuli $\mathrm{Du}^{1} \cdot \mathrm{Xu} \mathrm{Zhao}^{1}$
}

Published online: 5 June 2020

(c) Springer Nature B.V. 2020

\section{Correction to: Bulletin of Earthquake Engineering https://doi.org/10.1007/s10518-020-00827-x}

This erratum is being published to correct two reference mistake and equation symbol in the paper.

Before correction:

GB (50011-2010) Code for Seismic Design of Buildings China. Architecture and Building Press, Beijing (in Chinese).

Wolf JP, Paronesso A (1991) Errata: Consistent lumped-parameter models for unbounded soil. Earthq Eng Struct Dyn 20(6):597-599.

Equation (29): $\eta=1.0+\frac{0.05-\zeta}{0.08-1.6 \zeta}$.

After correction:

GB (2014) Code for Seismic Design of Urban Rail Transit Structures (GB 50909-2014). China Planning Press, Beijing (in Chinese).

Wolf JP (1991) Consistent lumped-parameter models for unbounded soil: physical representation. Earthq Eng Struct Dyn 20(1):11-32.

Equation (29): $\eta=1.0+\frac{0.05-\zeta}{0.08+1.6 \zeta}$.

Publisher's Note Springer Nature remains neutral with regard to jurisdictional claims in published maps and institutional affiliations.

The original article can be found online at https://doi.org/10.1007/s10518-020-00827-x.

Mi Zhao

zhaomi@bjut.edu.cn

1 Key Laboratory of Urban Security and Disaster Engineering of Ministry of Education, Beijing University of Technology, Beijing 100124, China 